\title{
The Making of Urban Peripheries and Peripheral Labor: Brick Kilns and Circular Migration in and beyond Greater Delhi
}

Pratik Mishra

\section{OpenEdition}

Journals

Electronic version

URL: https://journals.openedition.org/samaj/7276

DOI: 10.4000/samaj.7276

ISSN: 1960-6060

Publisher

Association pour la recherche sur l'Asie du Sud (ARAS)

\section{Electronic reference}

Pratik Mishra, "The Making of Urban Peripheries and Peripheral Labor: Brick Kilns and Circular Migration in and beyond Greater Delhi", South Asia Multidisciplinary Academic Journal [Online], 26 | 2021,

Online since 29 March 2021, connection on 11 May 2021. URL: http://journals.openedition.org/samaj/ 7276 ; DOI: https://doi.org/10.4000/samaj.7276

This text was automatically generated on 11 May 2021.

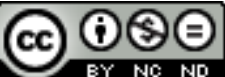

This work is licensed under a Creative Commons Attribution-NonCommercial-NoDerivatives 4.0 International License. 


\title{
The Making of Urban Peripheries and Peripheral Labor: Brick Kilns and Circular Migration in and beyond Greater Delhi
}

\author{
Pratik Mishra
}

\section{Introduction}

1 Different genealogies of the term periphery can be traced within the social sciences. It is foremost a relational concept, framed through a dialectical relation of "otherness" to the center. For Simone (2010), the periphery is a space of insufficiency and incompletion, "never brought fully under the auspices of the logic and development trajectories that characterize a centre, and therefore embodying an instability that is always potentially destabilizing of the centre" (p. 40). Such a figurative conception of the periphery informs this paper, where the periphery is not necessarily spatial but rather corresponds to "a range of fractures, discontinuities, or 'hinges' disseminated over urban territories" (Jacquier 2005:24 cited by Simone 2010:41). The other important framework within this paper, to understand the periphery, emerges from a political economic perspective, in which market-related metrics of value determine which activities have worth, and which are relegated to the margins. Urban scholarship has often engaged with the periphery on these terms, by looking at unequal regimes of land and population, livelihoods and values (Gururani 2019; Cowan 2019a). In this framework, the periphery becomes an essential component of capitalist accumulation that is flexibly produced through urban development politics seeking to turn the city into a conducive space for the flow of capital (Roy 2011).

2 Within urban studies literature, the term "periphery" has most prominently come to the fore in studies of geographies of the Global South. Much of this work has focused on the process of land transformation at the rural-urban interface and the complex state- 
society relations inscribed therein (Gururani 2019; Dubey 2018). The periphery has emerged as a heterogeneous category that has been traced across multiple sites and scales-at the urbanizing edges of expanding cities, disseminated across the fragmented physical and social structures of the core city, at distant sites of extraction along extended but discontinuous geographies of urbanization, and at the scale of the body, of socially stigmatized workers who do the hard, dirty work of reproducing the city, even sometimes at the cost of their own reproduction (Gidwani 2015).

3 This paper considers the periphery from a labor-centered reading, wherein its relational geography is indexed to the mobility of marginalized migrant workers and labor processes. Brick kilns are revealed to be a key site within these extended geographies of labor mobilities and show how the processes of exclusionary urbanization produce migrant workers as peripheral subjects, as a "people out of place" (Menon 2018), who keep switching between different low-wage occupations in the city and the kilns. This paper builds on a new and growing body of scholarship on labor-centered approaches to urbanization, and extends such work to the brick kilns as a specific entry point for capturing labor geographies of the urban. In particular, Gidwani's (2015) work on the critical "infrastructural labour" done by workers within the waste processing economy (also extended in Gidwani and Maringati 2016) is foundational to this paper. ${ }^{1}$

4 This paper attempts to rethink how the urban periphery can be reconceptualized from the vantage point of brick kilns and brick kiln workers. It considers the historical process of peripheralizing brick kilns (as an industry), shifting them away from the city, in tandem with brick kilns as a space to and from which workers circulate precariously. The paper, firstly, looks at the outward displacement of brick kilns from Delhi to its peri-urban villages through legislation, judicial rulings, and planning discourses. These actions were purportedly concerned with the objectives of maintaining economic land use, protecting public health and mitigating environmental pollution, but were underwritten, I argue, by a socio-spatial conception of the city that excluded certain categories of workers, livelihoods, and forms of work. I borrow from Sheetal Chabbria's (2020) research historicizing slum dwellings in Mumbai to understand brick kilns as social and spatial peripheries "incorporating and marking the edges of the city, that is not physical perimeters, but spaces and bodies of illegitimate or migrant labourers" (p. 18).

5 In continuing the understanding of peripheralization of brick kilns, the paper then turns to contemporary forms of circular migration and explores the various factors conditioning circular migration. It seeks to understand the reasons for which workers circulate between the brick kilns and different urban occupations at different moments in their lives. The myriad personal circumstances of the coming and going of kiln workers are structured along some key processes-meeting big expenditures through the brick kiln's lumpsum wage advances, managing bodily damage from strenuous labor, keeping one's family close or seeking escape from familial ties, being dispossessed of a painstakingly assembled urban livelihood or finally just managing kiln work and precarious urban employment side-by-side through the year. Workers find themselves in these circumstances or moments of vulnerability, as the paper describes, in such a recurrent and predictable manner so as to consider them structurally determined rather than simply personal contingencies or failures. 
6 The paper analyzes as a single articulated process both the displacement of brick kilns to the peri-urban and the precarious migration of brick kiln workers, and offers a spatial reading of these processes to highlight the tenuous relation of brick kiln workers to peri-urban space. By participating in different low-wage infrastructural economies, brick kiln workers provide vital services to the city but their cheap laboring bodies are kept peripheral and marginal to urban space, circumscribed within periurban brick kilns, through the mechanisms of urban development politics. Brick kilns emerge here as, what Gidwani and Maringati (2016:113) have described as an "infraeconomy," one that is denied recognition by state and civil society (except as an object of condemnation or reform) while also being critical to the production of urban space. The urban periphery understood from the perspective of brick kilns and the circulation of migrant kiln workers thus appears to be crucial and co-constitutive of the center.

7 The research draws on eleven months of doctoral fieldwork conducted between October 2018 and December 2019 in the village of Khanda in Sonipat district in Haryana on the northern edge of Delhi. The findings are based on the life histories of male brick kiln workers, particularly brick molders, collected through open-ended interviews. Brick molders or pather constitute over $80 \%$ of brick workers in any kiln and are the focus of my research. Throughout the paper, I use brick molders and brick workers or kiln workers interchangeably. My respondents were overwhelmingly male with only a handful of female interviewees. ${ }^{2}$ Male kiln workers enthusiastically presented me with rich travelogue-like accounts of the many different occupations and the corresponding geographies of these jobs. The patterns and motives that guided their migration trajectories emerged organically from over 150 unstructured interviews in which the collection of life histories was an important methodological orientation. In the discussion on circular migration, I present vignettes from different life histories and suggest they be taken anecdotally, so that their specificities are not lost to us, but also structurally as reflective of broader patterns.

\section{Locating the study: Khanda and brick work}

8 This section contextualizes the peri-urban fieldwork site of Khanda village, the work of brick-making and the social profile of the brick workers in this research. It then turns to the processes that led brick kilns to be shifted out of Delhi to places in the urban periphery, such as Khanda.

9 Khanda is a village located in Sonipat district, which is part of the National Capital Region (NCR). Though many villages in Sonipat have seen steeply rising land rates, the plotting and construction of multi-storied residential towers, industrial and educational zones, Khanda remains largely insulated from these processes. It is 29 kilometers away from the arterial Grand Trunk Road (or NH44) along which much of Sonipat's current urban development is centered (see Figure 1 for a map of Khanda). Khanda's peri-urbanity is instead manifest most significantly in the form of approximately 70 brick kilns, which were established by various private entrepreneurs, starting in 1997 but more actively between 2010-2015. The rise in number of kilns corresponds to the growth and expansion of Delhi and the NCR, which in turn produced a construction boom and a rapidly rising demand for bricks. Of the three major kiln clusters supplying bricks in the metropolitan region, Khanda is the second largest, providing employment to thousands of workers. ${ }^{3}$ By rough estimate, a population of 
around 30,000 migrants work and stay in these kilns for a full brick season, i.e. eight months from November to June. Across India, brick kilns employ between 2 to 10 million workers (sources vary). ${ }^{4}$

Figure 1. Location of Khanda in relation to Sonipat and Delhi.

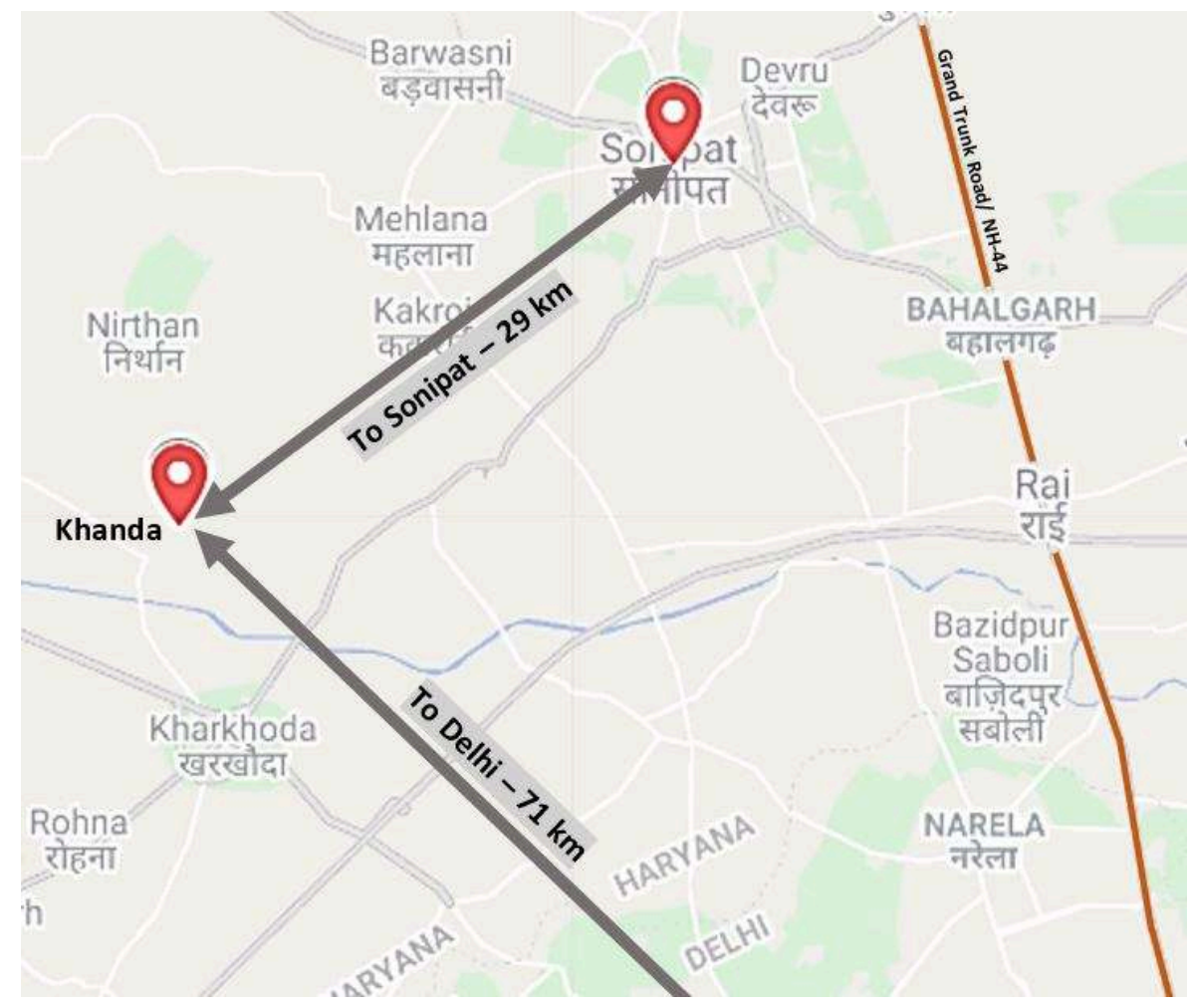

Brick kiln work is divided into different occupations. Roughly $80 \%$ of brick workers in any kiln are molders or pather who mold the wet soil into the shape of bricks and lay them out to dry. Other categories of workers in the kilns, such as jalaaiwala (firemen), buggiwala (horse-cart transporters) or beldar (stackers) usually belong to different caste groups, are subject to different politics of work and have other opportunities in terms of mobility than the pathers. ${ }^{5}$ Pathers usually live and work with their families, in scattered settlements on leased agricultural lands located near the kiln ovens. This decentralized production of bricks is carried out adjacent to the space of reproduction, in temporary jhuggis (huts) or tin-roofed shanties. The workers are predominantly from the landless and socially stigmatized Dalit or Scheduled Caste (SC) communities from Bihar, Chhattisgarh, and Uttar Pradesh. The major caste group is of Musahars from Bihar who are among the most marginalized castes in India, even among Dalits. There are many other caste groups from so-called "backward" communities (Scheduled Castes or Other Backward Classes) such as Paswan, Chamar, Kewat, Beldar from Bihar and Satnami, Rohidas from Chhattisgarh. 
Figure 2. Children turning over bricks laid to dry while a man works on molding them, and their jhuggi (makeshift dwelling) is in the background (Photo taken with permission, Source: the author)

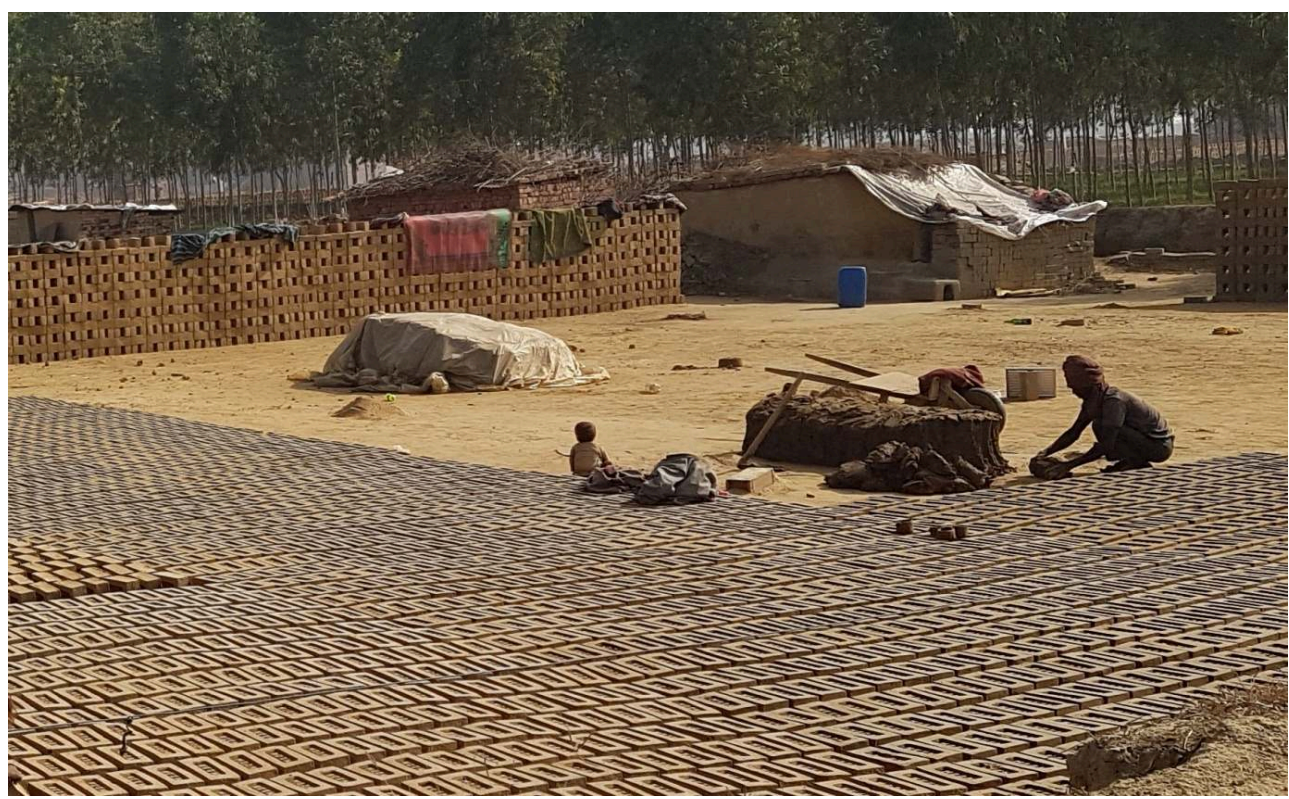

Brick work or molding is remunerated on a piece-rate basis of per thousand bricks rather than a daily wage or salary. During my fieldwork in 2019, Pathers would get Rs. 450 (excluding labor contractor's dues) for making a thousand bricks with preprocessed clay, and Rs.550 per thousand bricks if they prepared the clay manually themselves. The wages for brick molding are paid, however, under a debt bondage arrangement. Though unlawful under the Bonded Labour System (Abolition) Act, 1976, the system of the debt bondage, marked by the wage advance or peshgi, persists almost universally in the kilns (See Guerin 2013). Workers are recruited through labor contractors by paying a lumpsum advance at the beginning of the brick season in October. The wages from making bricks then accumulate against this advance and a fortnightly expense that the owner provides for buying rations, alcohol, medicine, and other necessities; the full wages are only paid in lumpsum at the end of the brick season in June, once the advance and all expenses have been deducted.

\section{The peripheralization of brick kilns in Delhi-NCR}


Figure 3. Exposed brick walls in a slum in Delhi (Source: Wikimedia Commons by Thomas Jessica)

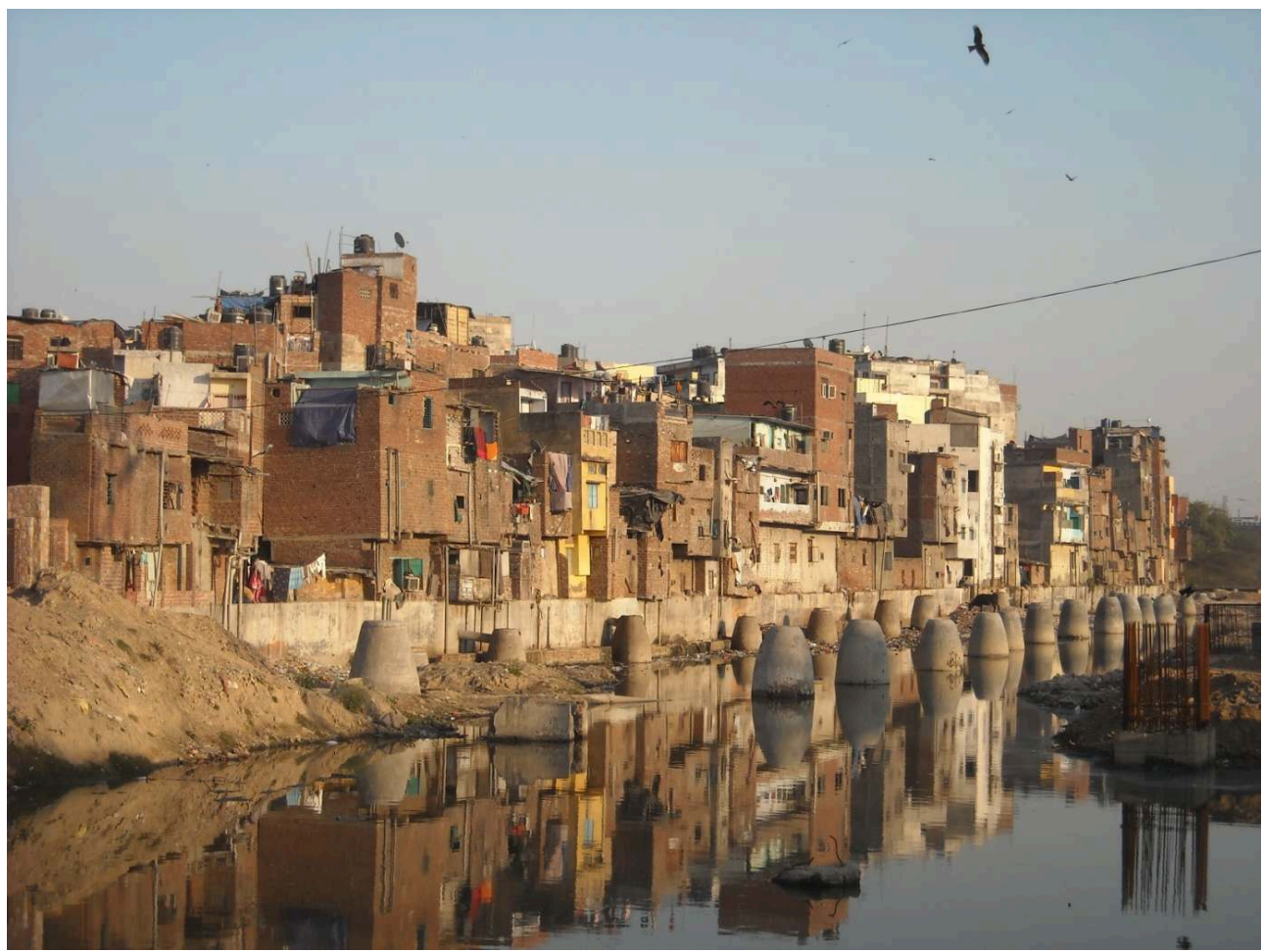

Most buildings in Delhi are constructed from red clay bricks. In a report on the waste generation of construction and demolition in India, the share of bricks in Delhi was over $40 \%$ by weight, the highest among major Indian cities (GIZ 2015:25). Exposed brick-and-mortar walls of red and grey are prominent in the urban landscape of slums and unauthorized colonies in Delhi, where $76 \%$ of the city's population live in informal settlements (Government of Delhi 2009: Table 1). Despite their vital importance for Delhi's urbanization, brick kilns have had a tenuous presence in Delhi's urban space. This history of this presence is marked by persistent effort on the part of the state to relocate kilns outside of the city while also negotiating the need for bricks in the city. In the colonial and early postcolonial period, the kilns were a mix of traditional clamps (puzhaayas or desi bhatta) and the more modern bull's kiln with a movable chimney (Eil et al. 2020). Technology and means of communication made the made the efficient management of brick supply from peripheral areas challenging, so businessmen preferred to use vacant spaces throughout the capital to set up kilns close to key residential areas with high construction activity.

The first attempt to regulate brick kilns was made under British administration in 1941 under the Delhi (Restriction of Use of Land) Act which provided for compulsory licensing of brick kilns (Delhi State Archives 1941). The aim of this regulation was to protect public health, not from smoke pollution but from the hazard of malaria, as mosquitoes bred in stagnant pools that formed over excavated land (brick fields) from which kilns drew soil. Colonial authorities had previously expressed alarm over unregulated new brickfields popping up in central areas of the city; the old brickfields (in the area south of Lodi road) had left the land uneven and the authorities estimated the expense to refill it would be substantial (DSA 1938:8). Placing restrictions on the excavation of soil, the 1941 act also established an annual renewal fee for kiln licenses that implied kilns were a temporary establishment (DSA 1941). 

industry. Brick kilns sprung up all around Delhi, responding to the burgeoning demand for housing, while struggling with coal shortages and commodity control laws. The Partition not only increased demand for housing, but also displaced erstwhile brick kiln owners from Pakistan who came to Delhi as refugees and set up kilns. In a 1953 letter to the first Chief Minister of Delhi, the Delhi Brick kiln owner's association mentioned that there were 175 registered kilns in Delhi out of which 50 were operated by Partition refugees and the kilns collectively employed 30,000 laborers (DSA 1953:34). The industry sought to project its critical role within the nation-building project and gain concessions from the state, as owners faced constant bureaucratic pressure with regard to non-renewal of licenses and displacement. In 1951, Delhi's Health Directorate had passed orders to disallow kilns within 2 furlongs (400 meters) of village and road boundaries (DSA 1953:23). Complying with this order proved difficult as continuous construction of new roads and colonies kept placing kilns in violation (DSA 1953:35).

Brick kilns were designated nationwide as a small-scale rural industry, and while the Ministry of urban development had a division to improve technological productivity and fuel efficiency of the kilns, the Khadi and Village Industries Corporation (a Government institution that promoted rural industry) provided loans for brick kiln entrepreneurs (Parliament Digital Library 1991a). There was a consistent drive to locate brick kilns out of the city. As India's malaria incidence dropped substantially in the late 1950s and 60s, air and smoke pollution became the dominant rationale for regulating brick kilns. The 1962 Master plan mandated that brick kilns be located beyond half-amile of the 1981 urbanizable limits of Delhi (DDA 1962). However, the actual project of removing brick kilns from the city remained incomplete, and proceeded at a gradual pace. New planned industrial districts that were plotted for Delhi to relocate "offensive and dangerous industries" and relieve congestion, instead of removing plants from the central city, became sites for the development of new industries (Sharan 2014). Despite the gradual peripheralization of brick kilns, in 1974-75, there were 400 brick kilns still located in Mehrauli, a locality on edge of South Delhi, and at least a few kilns continued to operate there until 1996 (Lucassen 2006:565). Supreme court judgment in 1996 in the landmark case M.C. Mehta vs. Union of India (Kathuria 2001). The case was filed as a public interest petition to implement the 1962 Master Plan, to complete the process of relocating polluting industrial units out of Delhi. Brick kilns were categorized in this case among the Category-H (noxious, hazardous) industries, and all 246 kilns operating in Delhi were ordered to close by June 30,1997 . This judgment also marked the end of operation of the highly polluting and outdated movable chimney kilns, still widely used at the time, as all the kilns located around Delhi had to build the fixed chimney bull's trench model. The 1997 judgment finally effected the relocation of brick kilns out of Delhi, decades in the making, and resulted in the kilns being firmly relegated to the peri-urban, if not rural, belts on the edges of Delhi. The clustering of kilns in places like Khanda and Badli today are the result of that ruling; they are spaces that were produced out of those wider urban development politics in conjunction with the changing geography of the city.

Thus, the peri-urbanization of brick kilns in Delhi was mainly based on public health and pollution arguments and labor's stake in this displacement was rarely a matter of concern. The welfare of labor did feature in some of the orders but appears secondary. 
The 1941 Delhi (Restriction of use of land) Act made minimum provisions for laborers a requirement for gaining a license but, in line with the public health concerns of the Act, this was motivated more by sanitary concerns, like the prevention of diseases, than labor welfare.

Historically, the actual implementation of labor rights and welfare in the brick kilns was limited, as the sparse archival materials show. One issue was the persistent undercounting of laborers. The 1962 Masterplan lists only 10,000 workers engaged in brickworks in Delhi, whereas the representation from the owners' association in 1954 mentions 30,000 workers. The number of kilns in Delhi in 1988, as per the state administration, was 388 and the Labour Ministry gave an estimate of 25,000 workers (PDL, 1991b; PDL, 1991c). This figure (64 workers a kiln), appears unrealistic given the usual density of workers.

Interestingly, the M.C. Mehta judgment in 1996 provided for payment of full wages and a "shifting bonus" of one year's wage for workers in industries affected by relocation. Whereas on paper this would provide brick molders compensation under the unskilled monthly minimum wage rate, in practice the actual wages in Delhi were based on piece-rate per thousand bricks. In any case, employee muster rolls were not maintained or were inaccurate (they still are) and kiln owners could easily circumvent this order by laying off casual laborers, who make up almost all the kiln labor force (See Baviskar 2012).

This historical indifference to the condition of labor in the displacement of brick kilns carries over to the present, at a time when a new round of outward displacement of brick kilns is underway, this time out of Khanda and the whole of the region of NCR into districts like Kurukshetra in Haryana, $150 \mathrm{~km}$ away from Delhi. In this contemporary round of peripheralization, the kilns are to be shifted out because of the stringently implemented air pollution measures that order the closure of all kilns in NCR till the start of February, i.e. 4 months later than start of the usual brick season (October).

21 This is being implemented under the Graded Response Action Plan (GRAP) formulated as a set of emergency measures to reduce air pollution in Delhi as the Air Quality Index turns "severe" in Delhi-NCR during the winter months. In 2018, the enforcement of this shutdown was lax and there was not much disruption to kiln work except around the festival of Diwali, when levels of pollution are especially intense (The Hindu Staff 2018). However, in the winter of 2019, the ban was stringently enforced, non-complying owners were fined and work was severely disrupted from October 15 till January 30, 2020 (fieldwork 2018, 2019). I observed that owners were unable or unwilling to build up inventory and stopped kiln workers from molding further bricks. This pushed kiln workers into a deep crisis, unemployed while their debt accumulated from both the lumpsum advance and the fortnightly stipends. Workers, who were afraid of not being able to work off the cumulative debt through this season, cut down consumption sharply. This also led many workers to activate their networks, and especially for young male workers to flee from the kilns to other work sites. Workers with families, however, were forced to stay.

The air pollution crisis emphasized how urban politics and environmental policies can adversely affect workers whose spatially distanced livelihoods depend upon the city and who get caught in the fallout of its policies. The city is identified as a privileged space, i.e. the beneficiary of the state's commitment to ensure the right to clean air for 
its residents, as opposed to protecting the livelihoods of thousands of workers engaged in a "noxious industry" such as the brick kilns. While some wealthy kiln owners with inventory could offset the loss from the pollution ban by selling bricks at a higher price (as demand overshot supply), workers bore the greatest brunt of the shutdown. The event also underscored the importance for workers of maintaining connections in different sites, of being able to circulate between kilns, and urban-based factories, and workshops.

\section{Producing peripheries through labor mobility} kiln workers, while taking into account their migration pathways and life histories. This approach to understanding peripheralization through mobility allows a direct engagement with different urban economies across which kiln workers circulate and their major motivations in doing so. In Khanda, the city is never far from view because the brick kiln cluster here exists primarily to service the urban metabolism of DelhiNCR. ${ }^{6}$

Even while taking brick kiln molders as a category of labor in this analysis, the paper establishes the occupational fluidity of this group between different city-based occupations and the kilns. Brick kiln molders in Khanda, belonging to different Scheduled Caste or Dalit communities of Bihar and Chhattisgarh, work in different periods of their lives (or seasonally) at construction sites, in waste processing, in factories, in addition to working in their native villages as agricultural laborers or marginal farmers. Kiln workers are therefore not clearly distinct in their migration trajectories or householding strategies from many other workers who constitute, as Breman (2010) describes, a reserve army of footloose labor in (peri-)urban India. The aim of this section is to examine the ways in which brick kilns serve as crucial nodes for specific social groups of workers, as they move across different sites of employment, navigating marginalization and precarity.

\section{Exclusionary urban processes}

The brick industry is an undesirable prospect for many workers. Kiln work carries low status, is associated with unfreedom (residing at the work site), poor living conditions (cramped temporary shacks) and the inability to educate children, thereby locking families into inter-generational poverty. For many kiln workers, permanence and social mobility is sought elsewhere, often through improvised and painstakingly assembled urban livelihoods amidst precarious attempts to survive in the city. Even as mobility can impart agency, workers always travel and labor as their casted and gendered selves and are often placed within relationships of dependency that render them precarious. Migrants who are from the social groups of kiln work often participate in infrastructural labor (Gidwani and Maringati 2016) crucial to the reproduction of urban space, but who, under an exclusionary urban regime, become anomalous figures "who cannot be dispensed with and who cannot be settled" (Samaddar 2016:53). The brick kilns, located in the distant peri-urban, become a part of this paradoxical "de-settling" of certain workers and their survival strategies. 
Parmeswar, along with his brother, lived in Anand Parbat, a working-class neighborhood of central Delhi, before moving to a kiln in Khanda. He had started a raddi (scrap paper) business, setting up a warehouse on 5 kattha (around 6,500 square feet) of Government land, that he had however "purchased" from a previous occupier. The surrounding area contained many such warehouses, and they had established it as a "Bihari colony," an address where the post office had begun delivering letters. Work was hard, and the contractors often rejected their collection for being too wet. Nevertheless, they occasionally had good months of profit and were looking to expand. However, in 2012, the Delhi Government carried out a slum demolition drive in Pandav Nagar (a colony in East Delhi) and designated their warehouse area in Anand Parbat for the resettlement of the displaced dwellers.

All our lands were taken. We protested, slept overnight in the site in the open, media had come, and police used lathi-charge and used tear gas on us on the demolition day. We had gone to every politician we could find. We met the head of the DDA [Delhi Development Authority], he would have given us 2-6 months extra to remove all the goods from the godown [warehouse], but he asked for a lot of money. I had taken up loans from a co-operative society for my business that I could not repay. My children used to go to school, now they are with me in the kilns. I hope I never come back here again and am able to restart my business in the future. (in-person interview, 2 February 2019)

Parmeswar's story alludes to Gidwani's (2015) and Gidwani and Maringati's (2016) conception of infra-economies, which particularly referenced stigmatized waste and sanitation work within the city and at landfills at the edges of the city. Parmeswar's marginal enterprise and the neighborhood waste economy inhabit, for Gidwani (2015), a "permanent border area of primitive accumulation" (p. 575), where it is constantly threatened as a devalorized activity, which takes up precious urban space that can be put to more profitable use. These micro-enterprise workers and owners, lacking any form of social security or employment protection, inhabit the thin line between survival and failure, and Parmeswar's migration to the kiln is an instance of the aftermath of dispossession and displacement for marginalized workers in the city.

For Parmeswar, his emotional investment into growing roots in Delhi was frustrated, though he was still determined to renew this effort. The relentless eviction of the urban poor leaves "even long-standing migrants in the city ... with a lasting sense of impermanence" (Shivanand 2020:4). For Menon (2018), who draws on the hinterland, a similar relational-spatial category as the periphery, the limits of the city come into view in respect to the dispossessed urban population, produced as a people out of place. The time-sensitive churning produced through acts of dispossession turn people into cheap, mobile labor productive for capital (before their eventual disposal) (Cowan 2020) and keep workers switching from construction work to street vending to other occupations, as well as turning to brick-making.

\section{Debt bondage and peripheral labor regimes}

Although migration to the kilns is often distress-related, it can also be strategic, as the labor regime and wage relations offer some advantages compared to other low-wage informal economies of the urban. The focus here turns to the wage advance system, a manifestation of debt bondage in kilns, underscoring how it is perceived by workers as continuous with other relations of informal employment in the city. Although 
technically illegal, the wage advance arrangement remains a resilient type of wage/ labor regime and is ubiquitous in brick work (Guerin and Venkatasubramaniam 2020). As workers explained, the wage advance can provide a bridge, acting against the "deficiencies" of other forms of urban work, enabling them to reproduce themselves, manage difficult life circumstances and even pursue modest accumulation. My field research highlights that the harsh distinction drawn between bondage and other forms of urban work, though not corresponding to these dynamic ground realities, nevertheless powerfully informed and continue to inform the peripheralization of kilns and kilnwork outside the city.

Manoj is a 55-year-old brick molder in Khanda. He started working in the kilns when he was very young. His parents were also brick-workers and he has spent most of his life working at brick kilns. During his life, he tried various occupations including different stints as a construction worker. For a year, he also worked as a cleaner in a private hospital in Delhi, away from his family. During that time, he was paid ₹12,000 monthly, of which he would spend ₹ 6,000 on groceries, ₹3,000 on rent, ₹500 on electricity bill and be left with only ₹2,500 for all other expenses. There was no scope for saving or for coping with a major expense. Urban employment for Manoj represented an improvement in his standard of living over the brick kiln shanties, but was accompanied by insecurity, long work hours and loneliness (akelapan). He joined the kiln as he needed to use the lumpsum cash from the wage advance for the hospitalization of a relative. ${ }^{7}$

In a recent paper, Guerin and Venkatasubramaniam (2020) compare the lived experience of workers within the wage advance arrangement in brick kilns against other market-based debts which are proliferating alongside the increased financialization of the domestic economy of migrant workers and their growing indebtedness. In understanding how one form of debt is articulated in relation to other forms of dependence, the authors draw out how unfreedom manifested through the wage advance relation is clearly differentiated by workers from older hereditary forms of bondage, mostly in agrarian settings. The wage advance system allows a degree of flexibility in managing the debt repayment, although it can also double up with market debt (Guerin and Venkatasubramaniam 2020). Laboring in the brick kilns under the wage advance arrangement carries significant risk as well. Because workers are paid on a piece-rate basis, periods of idleness because of rain or extraneous circumstances (such as the air pollution ban or COVID) exacerbate indebtedness both from the initial advance and the fortnightly maintenance stipend, and the entire eight-month season is often insufficient for workers to work off this debt (See Mishra 2020).

Chhabria (2020) looked at how colonial authorities sought to delimit the city of Bombay as the space of free labor (whether in industry or commerce) as opposed to the space of village as that of unfree labor (predominantly related to the agrarian). As I argued earlier, a similar conception of the urban underpinned attempts in Delhi to transfer industries such as brick kilns out of the city and to the peri-urban. Seeking to demarcate free and unfree labor, through methods such as approaching brick kilns as sites of debt bondage and modern slavery (see Davidson 2015), not only ignores the complex articulations of different forms of debt throughout the economy, but also risks perpetuating spatial practices that further disadvantage migrant workers in their circulations. Indeed, the illegality of the wage advance system, alongside its ubiquitous 
presence serve as a starting point in relegating brick kilns to a grey zone of unregulated activity in relation to labor rights.

\section{Bodily management}

33 A final manifestation of exclusionary urbanization that I discuss is in relation to the circulation of workers between different work economies and the kiln in embodied terms, as a corporeal strategy of preserving, managing, and repairing the body. The material (re)production of the built environment under capitalist urbanization is crucially dependent upon the reproduction of the low-waged migrant workers performing the labor of making bricks (see Buckley 2012). This includes not only paying wages but preventing workplace injury and protecting the worker's body against intense wear and tear. Workers likewise are heavily invested in managing their bodies, which are crucial for their labor-intensive livelihoods (Waite 2007:227).

For low-wage informal workers in India, however, the competition for wages and the extreme power differential between capital and labor means that they have to participate in systems of work that tend towards destroying their bodies or at least rendering them obsolete in exchange for basic (read: meager) or slightly premium wages. Migrant urban workers face this corporeal risk within several of the peripheral work economies where they are routinely exposed to hazardous and strenuous working conditions. The management of their vulnerable bodies is carried out through the everyday negotiation of bodily threats, but also by alternating between different kinds of embodied labors within different occupations. Because of its distinctly embodied labor, kiln work also becomes a part of the circuit through which workers churn across the rural and the urban in pursuing employment while managing their bodies (with attributes of strength, skill, injury) as primary assets.

Undertaking work as a pather (molder) is distinguished here by the form of concrete labor embodied in producing bricks. The work of pathaai or molding is one of dedication and repetition, its most significant aspect being the prolonged hours of squatting-systematically loading soil from a nearby lump into the mould, discarding the excess soil and laying the set soil-brick on the ground to dry, while moving sideways slowly for each new brick. This rhythm is painful for the first few monthsnew workers experience restricted blood flow to the feet, painful clots and knee pain from prolonged squatting. The speed of laying bricks also develops with experience, and so new workers only produce about half as many bricks as experienced workers. However, given that kiln work usually involves migration as a family, most kiln workers are inter-generationally socialized to this work, having worked alongside their parents as adolescent children.

Bablu is 40 years old, thin and balding with white hair, and previously worked in a granite shop in Bengaluru for 8 years. He worked in loading and unloading granite but had started apprenticing as a helper to learn "cutting-fitting" or the job of laying granite slabs. The wage on loading-unloading was decent at ₹700 daily (or ₹21000 monthly) and the work was only for an hour or so every day, though it was very hard labor. One morning his right arm suddenly lost its strength; he could barely lift it up. The doctor said it was because of his heavy lifting work and recommended that he do some other lighter work. Having worked in the kilns before, he returned to Khanda. He knows kiln work well and makes up to 2000 bricks in a day, which is more than what 
most workers manage. The long hours of molding bricks, squatting on his feet is strenuous but he does not want to return to Bengaluru. His arm has meanwhile recovered fully. ${ }^{8}$

Workers who are unable to cope with the bodily demands of work or wish to avoid risk often seek to change occupations. This act of escape can however impose a deep financial penalty upon workers. Human bodies are built out of our roles as paid workers (Guthman 2015) and this construction of bodies in line with occupations is crucial to the ways in which expertise is embodied and articulated within various manual labor jobs (see Sargent 2020). Brick work can often become a stage of employment after youthful energies are spent in more strenuous and higher-paying work. Most brick workers are middle-aged with children, proportionately fewer are young people in their 20s and 30s. Many brick workers continue till they are in their 60 s before they retire to their village to do agricultural labor in their own marginal holdings or upon others' land. ${ }^{9}$

The analytic of bodily management focuses attention not only on the socio-ecological processes converging upon the body within the extraction of labor power, but it also allows us to understand the reproduction of labor in the city as a multi-sited practice. Cowan (2019b) discusses the urban villages in Gurgaon as crucial infrastructural nodes that are embedded within migrant workers' daily reproduction as mobile labor power. ${ }^{10}$ The brick kilns, with opportunities for a differently embodied form of labor, similarly become sites of managing the corporeal burden of work, embedded into the social reproductive strategies of certain marginalized social groups.

\section{Sociality and seasonality in the urban periphery}

The previous section on exclusionary urbanization highlighted the distress aspect of kiln migration in relation to failed attempts to grow roots in the city or maintain stable migration links to the city. These attempts in themselves underscore the importance of considering both strategic and affective dimensions of migration, and how migration decisions are mediated by social and cultural aspirations. I propose to understand mobility between the kiln and the city in relation to maintaining and escaping social ties. Migration scholars in India have examined various social dimensions of migration, not limited to economic calculations or as a coping strategy in the context of vulnerability. In the context of brick kilns, Shah (2006) looked at brick kiln migration by young adivasi men and women from the state of Jharkhand in Eastern India as a means to gain independence from parents and live out prohibited intimate relationships.

In the case of Khanda, I was drawn to kiln sociality as an entry point to investigate the under-representation of a certain age group of young male molders in the kilns, those between 18 and 30 years of age. These were unmarried young men whose parents and siblings may be working in the kiln, but they were instead doing jobs in the city or the factory at this stage of their life. Brick kiln work, because of its association with bondage, is considered to be among the least prestigious parts of the laborscape (Waite 2005:424) and young men seek to do "factory work" or other occupations in the city for social distinction though they may be less lucrative.

41 The following is from a conversation with Amarnath, 16 years old, who aspires to work in the city: "I don't like it in the kilns (man nahi lagta). A person becomes black (dark- 
skinned) working here. Person becomes spoilt, drinking, eating tobacco, smoking bidis. The height also stops growing here. I like working in the city. You cannot study here, though you cannot study in company work also. But there is a difference, there is no growth of intelligence in the kilns (yahaan akal nahi badhti)." ${ }^{11}$ Amarnath frames the city as a place where one can become hoshiyar (intelligent; tactful), as opposed to the mundane straightforward way of life in the kilns. ${ }^{12}$

For those who grow up working within the kilns alongside their parents, the connection to the kilns is rarely lost as extended family members continue to migrate there, and also because every year during the recruiting season, they must face the decision of whether to return to the kilns or not. The return may be made on grounds of restoring a stability of life, and on affective grounds of experiencing loneliness and wishing to live alongside family members. With marriage and children, male workers become more inclined to migrate to the (peri-urban) kilns instead of the city. Nagina-ji, a middle-aged worker from Nalanda in Bihar, articulated the major advantage of working in the kilns as the opportunity to keep family and children close at hand, so that any major incidences and adversities are not communicated by phone from hundreds of miles away.

Kilns thus become a key site within the translocal householding strategies for families who rely on spatially stretched relations of social reproduction. The distribution of the household across locales is not only a strategy of survival, a process of hedging as Simone (2021) suggests, but also one of mediating aspirations, of seeking a temporary or permanent escape towards a more respected urban occupation, or, under the pressure or desire to maintain family ties, settling for the brick kilns amidst the drab peri-urbanity of it all.

\section{Seasonality of mobility}

Against these longer-term motives and patterns of migration, we now turn to shorterterm mobility, especially seasonal mobility, among brick workers. Against the routine flow of workers from the peri-urban to the urban in the form of the daily commute, the occasional short-term migration of many brick workers between the peri-urban kiln and the city nevertheless establishes a further aspect of how urban regions are dependent upon peri-urban economies and flows. Tracking the ways by which brick kiln workers participate in diverse urban occupations, most notably at the end of the brick season, is important for understanding different labor markets in the urban economy. ${ }^{13}$

Brick kiln migration in India itself is mostly takes on the form of short-term mobility of less than six months. Short-term migrants in brick-kilns constitute the second largest segment of the non-farm workforce after those in the construction sector (Roy and Kunduri 2018). This is not so however in North India and around major cities where the rain season is shorter, and where larger kilns manage greater brick demand and require long-term migrants for 6-8 months. While most kiln workers classified as "rural-to-rural migrants" return to their village after the brick season, many workers intermittently continue as migrants in some years, looking for other occupations. Some stay on in Khanda and do odd jobs while others work in Delhi or Sonipat over this period, cutting down their annual visit to Bihar to just a few days rather than four 
months. This extension may or may not be distress-driven but is usually pre-planned and structured around stable networks of short-term employment.

My final vignette is of Vijay Kumar who is 42-years old from Nalanda district in Bihar. $\mathrm{He}$ is among the few molders who had come to Khanda with a male colleague, not with his family.

I ply a rickshaw (cycle taxi) during the choumasa (monsoon) when there is no work in the kilns. I have a wife and two young kids in the village. Money is still not enough. The people who have big families where all are working have bigger incomes, I am alone here while my wife looks after my parents and the kids. I send money most every fortnight to my family from the kharcha, and so there is hardly anything left over at the end. If I have a good season, where I return with Rs.10-20,000, then I will not ply the rickshaw anymore. Or if there is any good work at home.

I drive the rickshaw in Azadpur in Delhi, within a radius of $5 \mathrm{~km}$ or so. I pay ₹50 daily rent on the rickshaw. In a day, after all expenses, I usually make around ₹ 200. We rent a room, around twelve of us from my village and stay in Azadpur. The last season was bad, so I did the rickshaw work and only visited my family for 2 weeks. (In-person interview, 2 December 2019)

Vijay's situation is atypical of the kilns because he did not migrate with his family but it is not rare. The seasonal work as a rickshaw-puller is not surprising-because of low barriers of entry, it is seen as a relatively easy livelihood for short-term work in the city and is pursued by the poorest among the various urban informal workers (Samanta 2016; Begum and Sen 2004). Although it appears to be a form of selfemployment, the drivers have no ownership or control over the means of production, often ply the rickshaw illegally against urban regulations, and so are akin to sellers of labor power (Samanta 2016).

Many kiln workers do not return to their home villages during the monsoon. Jobs on construction sites, especially less-skilled occupations like bricklaying (chinai) draw from the same pool of workers as the kilns, and many kilns engage in construction work during this period. In the entanglement of brick and construction labor, it is useful to keep in mind the impact of migrant circulation in construction work upon the seasonal fluctuation in brick prices.

Around the month of April, the wheat harvest across North India takes off in full swing, causing widespread labor shortages. Many construction workers who are not tied to long-term projects but employed on a flexible basis, leave the city to take part in the harvest in their villages. Much of the construction labor force in our cities, as described in Samaddar (2016), works as roving bands of laborers moving from one construction site to another. For instance, they work for 20 days harvesting wheat in Punjab, Uttar Pradesh, and Haryana, and often do not return to construction work until they have exhausted their money. The one to two-month disruption produced by this phenomenon slows down construction work significantly, especially individual house building and repair work on which most of the brick industry is dependent. When the demand for bricks falls kiln owners reduce prices to offload excess inventory, marking the lowest-price point for the year (for 2019, below Rs.4,000 as opposed to a normal price point of Rs.4,500 for first-grade bricks). Conversely, the high-price season for bricks (above Rs.5,200) is after the monsoons in September, when construction work resumes in full swing, while brick stocks are low and kiln labor is still just beginning to come in. Thus, the seasonal fluctuation in brick demand is closely tied to migrant 
circulation, and is likewise observed in the urban periphery, where settlements and activities swell and contract in rhythm.

\section{Conclusion}

51 This paper has attempted to rethink the urban periphery from the vantage point of peri-urban brick kilns and brick kiln workers, in other words, to consider the periphery from a labor-centered perspective using a relational geography approach. It has drawn a parallel between the displacement of brick kilns from Delhi to peri-urban villages in Haryana and the precarious migration of brick kiln workers as related processes, highlighting the tenuous relation of brick kiln workers to urban space.

The Haryana village of Khanda is connected to Delhi-NCR because it is part of its urbanizing frontier, and also because of the hundreds of millions of bricks it supplies every year for the construction and repair of a wide variety of buildings, from slum dwellings to middle-class apartments to glass and concrete office buildings and malls, to public roads and canals. The paper argues that the presence of brick kilns and their historical outward displacement from Delhi implicates Khanda within a series of temporary peripheral landscapes through different periods of Delhi-NCR's growth. Brick kilns are marked as spaces of "otherness," considered both harmful to the city's residents and environs and out of place with regard to spatial conception as a globalizing city. The gradual peripheralization of brick kilns came about as a result of urban development politics, manifested through laws, judicial rulings and planning discourses. This process displaced kilns to the periphery, and also rendered "peripheral" thousands of workers, which is also apparent from their relative absence in the archival record on brick kilns.

paper complements this historical register with specific aspects of labor migration to brick kilns in the contemporary moment. Brick kilns, as a large-scale system of employment, are sustained by, and set into motion a circulation of laboring bodies that ties together disparate sites, from the remote hamlets of Bihar to the brickfields of peri-urban Khanda, to small urban enterprises such as scrap dealers and granite shops. By revealing some of these connections, I argue that brick kilns not only produce bricks as a commodity but are also an important node in the circuit of migration of low-waged marginalized workers whose infrastructural labor is crucial to the production of urban and peri-urban space. Migrant workers invest their labor power and in conjunction, their embodied selves into those destinations that become available through their social networks of trust, basing their choice not only upon the differing mixes of aspiration and security that these destinations offer but also perforce in dealing with various life circumstances.

The research paid specific attention to these different economic and life circumstances. Mirroring the disparate sentiments of azadi and akelapan (freedom and loneliness) that Sethi (2011) poignantly explored within the laboring life of a casual laborer in old Delhi, my research also encountered a range of emotions-contentment, frustration, boredom-that could only be partially explored within the paper. The paper sought to bring out the spatial bearings of these decisions and emotions and locate them along the peri-urban co-ordinates of the kilns or the co-ordinates of various city-based occupations. It has argued that exclusionary urbanization processes, in tandem with migrants' life cycle choices, have contributed to the production of migrant workers as 
peripheral subjects while simultaneously co-producing the urban periphery. The periphery, read through a register that juxtaposes urban development politics against brick workers' circulations, allows us a deeper understanding of the forces against which workers seem powerless and those that they actively resist.

\section{BIBLIOGRAPHY}

Baviskar, Amita. 2012. "Public Interest and Private Compromises: The Politics of Environmental Negotiation in Delhi, India.” Pp. 171-201 in Law against the State: Ethnographic Forays into Law's Transformations, edited by J. Eckert, B. Donahoe, and C. Strumpell. Cambridge: Cambridge University Press. doi: 10.1017/CBO9781139043786.008.

Begum, Sharifa and Binayak Sen. 2004. "Unsustainable Livelihoods, Health Shocks and Urban Chronic Poverty: Rickshaw Pullers as a Case Ctudy." CPRC Working paper 46. Dhaka: Bangladesh Chronic Poverty Research Centre. doi: 10.2139/ssrn.1754402.

Breman, Jan. 2010. Outcast Labour in Asia: Circulation and Informalization of the Workforce at the Bottom of the Economy. New Delhi: Oxford University Press.

Buckley, Michelle. 2012. "Locating Neoliberalism in Dubai: Migrant Workers and Class Struggle in the Autocratic City." Antipode 45(2):256-74. doi: 10.1111/j.1467-8330.2012.01002.x.

Chhabria, Sheetal. 2020. Making the Modern Slum: The Power of Capital in Colonial Bombay. Hyderabad: Orient Blackswan.

Cowan, Tom. 2019a. "The Village as Urban Infrastructure: Social Reproduction, Agrarian Repair and Uneven Urbanization.” ENE: Nature and Space 0(0):1-20. doi: 10.1177/2514848619868106.

Cowan, Tom. 2019b. "The Urban Village, Agrarian Transformation, and Rentier Capitalism in Gurgaon, India.” Antipode 50(5):1244-66. doi: 10.1111/anti.12404.

Cowan, Tom. 2020. "Rooted Flexibility: Social Reproduction, Violence and Gendered Work in the Indian City." Gender, Place \& Culture 28(1):66-87. doi: 10.1080/0966369X.2019.1708276.

Davidson, Julia O. 2015. Modern Slavery: The Margins of Freedom. Hampshire: Palgrave Macmillan. Delhi Development Authority. 1962. Master Plan of Delhi: Work Studies. Vol. 1. P. 21.

Delhi State Archives. 1938. File No. 1301. Local Self Government. Chief Commissioner Office. Delhi State Archives. 1941. File No. 15-30-1. Local Self Government. Chief Commissioner Office. Delhi State Archives. 1953. File No. 2-1. Chief Minister's Secretariat. Chief Commissioner Office. Dubey, Shruti. 2018. “Urban Transformations in Khora Village, NCR.” Economic \& Political Weekly 53(12):77-80.

Eil, Andrew, Jie Li, Prajwal Baral, and Eri Saikawa. 2020. Dirty Stacks, High Stakes: An Overview of Brick Sector in South Asia. World Bank. Retrieved March 4, 2021 (http:// documents1.worldbank.org/curated/en/685751588227715919/pdf/Dirty-Stacks-High-Stakes-AnOverview-of-Brick-Sector-in-South-Asia.pdf). 
Gidwani, Vinay. 2015. “The Work of Waste: Inside India's Infra-economy.” Transactions of the Institute of British Geographers 40(4):575-95. doi: 10.1111/tran.12094.

Gidwani, Vinay and Anant Maringanti. 2016. "The Waste-Value Dialectic: Lumpen Urbanization in Contemporary India." Comparative Studies of South Asia, Africa and the Middle East 36(1):112-33. doi: $10.1215 / 1089201 x-3482159$.

GIZ. 2015. Resource Efficiency in the Indian Construction Sector: Market Evaluation of the Use of Secondary Raw Materials from Construction and Demolition Waste. Retrieved March 4, 2021 (https:// www.devalt.org/images/L2_ProjectPdfs/

MarketevaluationreportforrecoureefficiencyusingCDwaste.pdf?Oid=122).

Government of Delhi. 2009. “Delhi Economic Survey 2008-09.” DOE Affairs. Government of Delhi. New Delhi.

Griffiths, Melanie, Ali Rogers and Bridget Anderson. 2013. "Migration, Time and Temporalities: Review and Prospect." Retrieved March 4, 2021 (www.compas.ox.ac.uk/2013/migration-timeand-temporalities-review-and-prospect/).

Guérin, Isabelle. 2013. “Bonded Labour, Agrarian Changes and Capitalism.” Journal of Agrarian Change 13:405-23. doi: 10.1111/joac.12029.

Guérin, Isabelle and G. Venkatasubramaniam. 2020. "The Socio-economy of Debt. Revisiting Debt: Bondage in Times of Financialization.” Geoforum. doi: 10.1016/j.geoforum.2020.05.020.

Gururani, Shubhra. 2019. "Cities in a World of Villages: Agrarian Urbanism and the Making of India's Urbanizing Frontiers.” Urban Geography 41(7):971-89. doi: 10.1080/02723638.2019.1670569.

Guthman, Julie. 2015. "Binging and Purging: Agrofood Capitalism and the Body as Socioecological Fix." Environment and Planning A 47:2522-36. doi: 10.1068/a140005p.

Jacquier, Claude. 2005. “Can Distressed Urban Areas Become Poles of Growth?” Pp. 381-93 in OECD International Conference Sustainable Cities: Linking Competitiveness with Social Cohesion. Montreal: OECD Publishing.

Kathuria, Vinish. 2001. “Relocating Polluting Units: Parochialism vs. Right to Live?” Economic \& Political Weekly 36(3):191-95.

Lucassen, Jan. 2006. "Brickmakers in Western Europe (1700-1900) and Northern India (18002000): Some Comparisons.” Pp. 513-73 in Global Labour History: A State of the Art, edited by J. Lucassen. Bern: Peter Lang.

Menon, Gayatri A. 2018. "People Out of Place: Pavement Dwelling in Mumbai." Economic \& Political Weekly 53(12):85-92.

Mezzadri, Alessandra. 2016. "Class, Gender and the Sweatshop: On the Nexus between Labour Commodification and Exploitation." Third World Quarterly 37(10):1877-1900. doi: 1080/01436597.2016.1180239.

Mishra, Pratik. 2020. "Urbanisation through Brick Kilns: The Inter-relationship of Appropriation of Nature and Labour Regimes.” Urbanisation 5(1):17-36. doi:10.1177/2455747120965199.

NSSO. 2014. Employment and Unemployment Situation in India 2011-2012. NSS Report No. 554 (68/10/1). New Delhi: National Sample Survey Office, Ministry of Statistics \& Programme Implementation, Government of India.

Parliament Digital Library. 1991a. Part-1. Question No. 3669 by Naresh Ku Baliyan. August 21, 1991. 
Parliament Digital Library. 1991b. Part-1. Question No. 3399 by Gaya Prasad Kori. August 19, 1991.

Parliament Digital Library. 1991c. Part-1. Question No. 4326 by Gaya Prasad Kori. August 26, 1991.

PCLRA. 2012. Wage Labour Atlas of Brick Kiln Workers. Prayas Centre for Labour Research and Action, and Aga Khan Foundation. Retrieved March 4, 2021 (https://www.clra.in/files/ documents/Wage-Labour-Atlas-of-Brick-Kiln-Workers-final-July12.pdf).

Roy, Ananya. 2003. City Requiem, Calcutta: Gender and the Politics of Poverty. Minneapolis: University of Minnesota Press.

Roy, Ananya. 2011. “Slumdog Cities: Rethinking Subaltern Urbanism.” International Journal of Urban and Regional Research 35(2):223-38. doi: 10.1111/j.1468-2427.2011.01051.x.

Roy, Shamindra Nath and Eesha Kunduri. 2018. Migration to Brick Kilns in India: An Appraisal. Policy Brief. Centre for Policy Research. Retrieved March 29, 2021 (http://

www.indiaenvironmentportal.org.in/files/file/

Migration\%20to\%20Brick\%20Kilns\%20in\%20India.pdf).

Samaddar, Ranabir. 2016. "Migration and the Neoliberal City: An Introduction." Economic \& Political Weekly 51(26-27):52-54.

Samanta, Gopa. 2016. “Mobility, Marginality, and the Cycle-rickshaw in Indian Cities.” Pp. 311-27 in Spatial Diversity and Dynamics in Resources and Urban Development, edited by A. Dutt, A.G. Noble, F.J. Costa, R.R. Thakur, and S.K. Thakur. Dordrecht: Springer.

Sargent, Adam. 2020. "Working against Labor: Struggles for Self in the Indian Construction Industry.” Anthropology of Work Review 41:76-85. doi: 10.1111/awr.12199.

Schling, Hannah. 2018. “(Re)production: Everyday Life in the Workers' Dormitory." Society and Space 7. Retrieved 29 March, 2021 (https://www.societyandspace.org/articles/re-productioneveryday-life-in-the-workers-dormitory).

Sethi, Aman. 2011. A Free Man: A True Story of Life and Death in Delhi. New York: W.W. Norton and Company.

Sharan, Awadhendra. 2014. In the City, out of Place: Nuisance, Pollution, and Dwelling in Delhi, c. 18502000. Delhi: Oxford University Press.

Shivanand, Swathi. 2020. “'Feet in Both Places': Affective Spaces of Circular Migration." Urbanisation 4(2):94-108. doi:10.1177/2455747119892346.

Simone, Abdou Malique. 2010. City Life from Jakarta to Dakar: Movements at the Crossroads. Abingdon: Routledge.

The Hindu Staff. 2018. "NGT Raps Delhi, Other States." The Hindu, April 6. Retrieved January 21, 2021 (https://www.thehindu.com/news/cities/Delhi/ngt-raps-delhi-other-states/ article23448437.ece).

Waite, Louise. 2005. "How is Labouring Enabled through the Body? A Case Study of Manual Workers in Rural India.” Contemporary South Asia 14(4):411-28. doi: 10.1080/09584930600839107.

Waite, Louise. 2007. “'Some people drink as the body should feel a little ease': Understanding Body Management amongst Manual Labourers in Western India." Journal of South Asian Development 2(2):227-53. doi: 10.1177/097317410700200203. 


\section{NOTES}

1. Other compelling studies in this vein include Roy (2003), who centered her research in the urban peripheries of Kolkata on the politics of migrant workers' livelihoods based around squatting and commuting within the city. Also, Buckley's (2012) rich intersectional scholarship on construction workers in Dubai ties gendered relations of production and social reproduction of construction workers into the politics of urban construction and foregrounds the role migrants play within capitalist processes of urbanization.

2. It was difficult to hold conversations with the few willing women kiln workers because invariably, when I asked a question of a women, a man nearby stepped in to answer the question from his perspective or on her behalf. As a cis male researcher, I found it difficult to persist in my attempts to engage with the women workers.

3. Badsa cluster in Jhajjar district and Baghpat cluster are the first and third largest clusters respectively. Large brick kilns have a production capacity of more than 30,000 bricks a day. See Mishra (2020) for a discussion of the emergence of Khanda as a kiln cluster based on its proximity to Delhi and the availability of cheap land predicated on the history of agrarian decline in Khanda.

4. 2.1 million according to the NSSO $68^{\text {th }}$ Round, 2011-12 (NSSO 2014) and 10 million according to International Labor Organization estimates (PCLRA 2012:10).

5. In these other occupations, the men belong mainly to the OBC (Other Backward Classes) or the erstwhile peasant and pastoral castes and may be from neighboring districts of Uttar Pradesh or Haryana.

6. A separate paper (Mishra 2020) looks at the situated, everyday laboring and soil extraction processes within Khanda as a manifestation of extended urbanization.

7. In-person interview, 11 December 2019.

8. In-person interview, 16 November 2019.

9. These figures are indicative; it was my intention to collect quantitative data among workers, but this plan was cancelled due to the Covid-19 pandemic.

10. See also Schling (2017) who takes the space of employer-provided workers' dormitory as a (degraded) space of repair, one that is deeply inscribed into a bodily regime that produces disposability.

11. In-person interview, 18 November, 2019.

12. The quest for urban employment is also highly gendered and mediated by naturalized tropes of the masculinized laboring body (Mezzadri 2016). Ideologies and practices of mobility incorporate young male kiln workers tightly into processes of flexibilization of labor within industrial production regimes in towns and cities, where workers are required to constantly move across firms, contractors, tenements and the city (Cowan 2020).

13. A focus on short-duration circular migration is especially important because, as Griffiths, Rogers and Anderson (2013) lay out, decisions to migrate are "on-going, complex and often opportunistic rather than planned" (p. :16). Mobility is nonlinear and mediated by such factors such as repetition, simultaneity, seasonality, and cycles (Griffiths et al. 2013:16). 


\section{ABSTRACTS}

The paper proposes a reading of the urban periphery from a labor-centered perspective, according to which its relational geography is indexed to the mobility of marginalized migrant workers and labor processes. Specifically, it attempts to rethink the urban periphery from the vantage point of peri-urban brick kilns and brick kiln workers. The paper draws parallels between the displacement of brick kilns to the peri-urban and the precarious migration of brick kiln workers by highlighting the tenuous tie between brick kiln workers and the urban space embedded in both. The paper first outlines the historical process of the outward displacement of brick kilns from Delhi to peri-urban villages in Haryana as a result of various pieces of legislation, judicial rulings and planning discourses. It then turns to contemporary forms of circulation between the kilns and the core city. Drawing from fieldwork data generated out of kiln workers' life histories, it explores the various factors conditioning mobility and the reasons why workers circulate between the brick kilns and different urban occupations at different moments in their lives. The paper argues that exclusionary urbanization processes, in tandem with migrants' life cycle choices, produce migrant workers as peripheral subjects while they contribute to the production of the urban periphery.

INDEX

Keywords: circular migration, periphery, brick kilns, peri-urban, bondage, body

\section{AUTHOR}

PRATIK MISHRA

Department of Geography, King's College London 